\title{
When the Kids Move Back Home ${ }^{1}$
}

\author{
Lynda Spence and Larry Forthun ${ }^{2}$
}

Recent trends show that more and more adult children are returning to live with their parents. They are returning home for a variety of reasons-an uncertain economy, military deployment, incarceration, or outstanding student loans, among others. ${ }^{1}$ For instance, a recent report by the Pew Research Center showed that ten percent of young adults age 18 to 34 reported the poor economy forced them to move back home. ${ }^{2}$ Adult children between the ages of 18 and 29 are referred to as "emerging adults" and represent the age group most likely to return home. ${ }^{3}$

Adult children who have their own children are also moving back home at increasing rates. According to a 2012 Pew Research study, $13 \%$ of parents with grown children say at least one of their adult children has moved back home in the past year. ${ }^{2}$

With intergenerational cohabitation on the rise, it's a good idea to examine the "what-ifs" before the doorbell rings. If you find yourself making up spare rooms for your grown children or even their children, you will be glad you thought about the issues in advance. This publication discusses the potential challenges and practical matters you need to know about if your adult children move back home.

\section{Set Boundaries}

Set boundaries up front to ensure everyone is on the same page about the living arrangements. Talk with your adult child about the length of the stay, whether it is for a specific duration (e.g., only a few months), or until she or he has achieved some goal (e.g., until she or he is retrained,

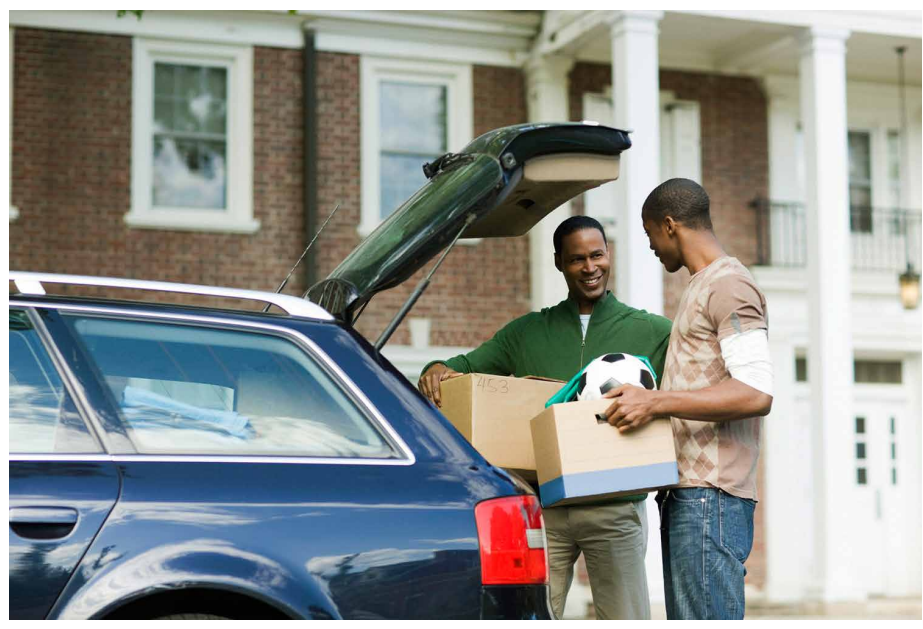

Figure 1. Credits: Fuse

graduated college, or saved up a predetermined amount of money). You may want to examine a rental agreement and use it as a guide for your own plan. Does this sound extreme? Maybe so, but you will thank yourself for your attention to detail if the waters get tested.

\section{Financial Assistance}

Initially, your adult child may need more than just a roof over her or his head; she or he may need financial assistance. ${ }^{4}$ If you are in a position to provide assistance, discuss with your adult child the criteria and limits of that assistance by answering the following questions:

1. This document is FCS2331, one of a series of the Department of Family, Youth and Community Sciences, UF/IFAS Extension. Original publication date: July 2013. Visit the EDIS website at http://edis.ifas.ufl.edu.

2. Lynda Spence, UF/IFAS Extension agent, UF/IFAS Extension Marion County; and Larry Forthun, associate professor, Department of Family, Youth and Community Sciences; UF/IFAS Extension, Gainesville, FL 32611. 
- Will financial support be treated as a gift or loan?

- How much will you contribute?

- Will you establish a predetermined amount or will it be on an "as-needed" basis? If so, what constitutes "need" and who will make that determination?

- If support is deemed a loan, what are the terms? Spell out the duration, amount, and purpose, or perhaps even draw up a legal contract.

- What constitutes a violation of the arrangement? Be as specific as possible.

- Will your adult child work? Will he or she take a shortterm job or hold out for a strategic career opportunity?

Because this is uncharted territory, trial and error may inform your guidelines. Changes in your agreement and a renewal option should be at your discretion.

\section{Household Expenses}

There will be other financial concerns as costs increase with additions to your household. You may find that your current monthly cost for food, utilities, etc., will almost double with the addition of household members. ${ }^{5}$ Estimate how much your household costs will increase and then discuss with your adult child how the costs will be shared. For example, will contributions be in cash or traded out in work? Likewise, discuss ways to save costs, such as frequency of eating out, where to set the thermostat for the HVAC/furnace and hot water heater, length of showers, and use of water for washing cars, turning off lights, etc.

Depending on the number of new family members in your household, food and meals can likely lead to the greatest increase in expense. Some questions to ask include the following:

- Will there be a change in the type of food purchased and prepared?

- Who will pay for special requests?

- What are the expectations for mealtime? Will the family eat together? How often?

- Who will prepare the food?

- Will everyone eat together?

- What about dinner guests?

\section{Chores}

You also want to discuss sharing responsibility for chores and general household maintenance. Who will be assigned to do various chores and when do they need to be completed? Who will do cooking, cleaning, shopping, laundry, yard maintenance, etc. Again, consider drawing up an agreement about household chores.

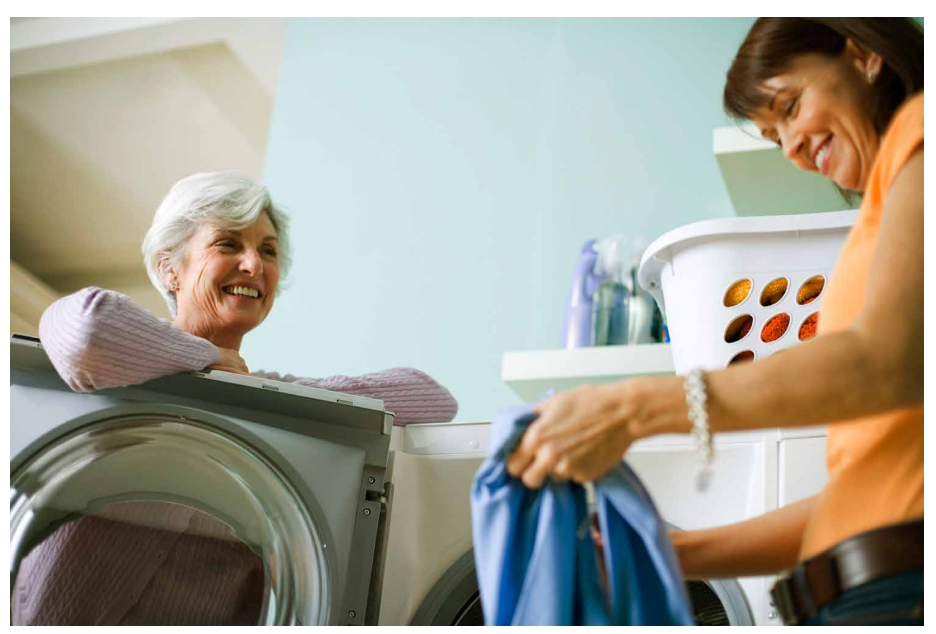

Figure 2. Credits: Fuse

\section{Grandchildren}

In some cases, grandchildren or grandchildren and their parents might move into the home with you. Children feel better when they know what is expected of them and who is in charge. Although you are not the child's parent, your relationship with your grandchildren will likely change when they move into your home. ${ }^{6}$ You may assume some co-parenting responsibilities, especially when the child's parent is working, in school, or otherwise not at home. Some issues to consider for grandchildren include the following:

- How will discipline be handled?

- What about child care?

- Will you designate an area for play? For entertaining? For study?

- Are there already guidelines in place for completing homework assignments, etc.? Is there a designated homework hour? Before TV? Phone? Social media?

- Will the family share a computer, or do your grandchildren have their own devices? What will the rules be? Who will monitor the rules?

- What will be expectations for bedtime, quiet times, and noise levels?

- Will the kids have their own $\operatorname{room}(\mathrm{s})$ ? Can they decorate their room? Hang pictures, etc.? 


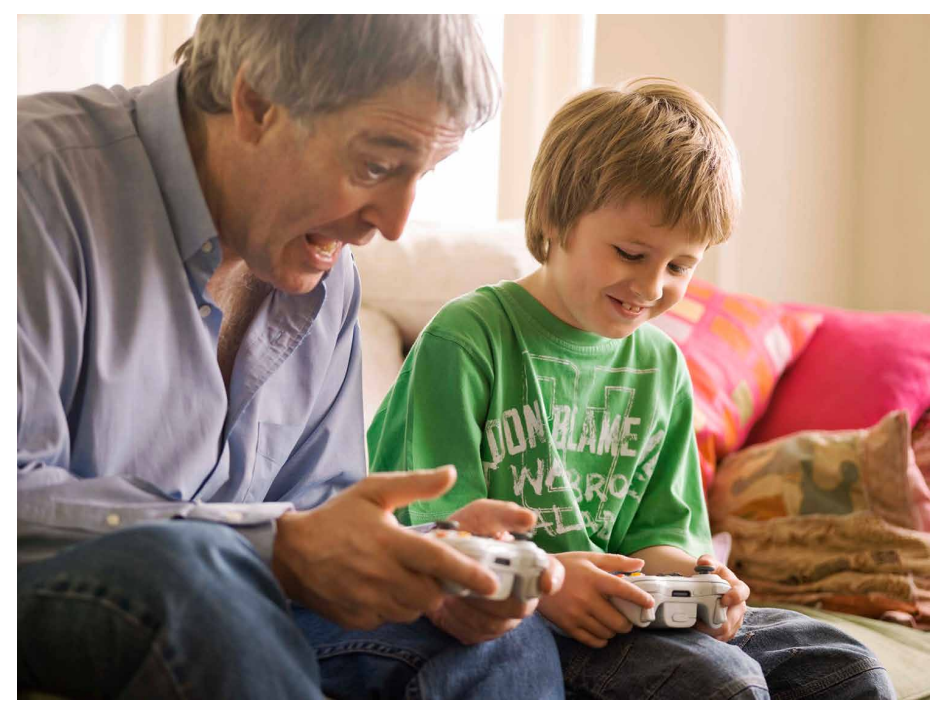

Figure 3. Credits: Bananastock

\section{Storage}

Only so much can fit in a house. Will your home accommodate the extra things if your children move back home? Do you have an attic or basement or garage? Is there room to stash objects? Will your child need to rent a storage unit?

\section{Visitors}

The addition of family members in your household includes more friends and visitors. You will want to discuss how visitors will be handled, especially overnight visitors.

\section{Transportation and Parking}

Likewise, discuss transportation and parking arrangements. Will your car become the family car again? Who will pay for gas, repairs, and insurance? In Florida, if a driver is under 25 and has a poor driving record, the rate hike is substantial. ${ }^{7}$ How will you share the vehicle? Will it be used on a first come, first served basis? You may want to develop a sign-out sheet. See the example on the following page (Table 1).

\section{Summary}

As Yogi Berra so wisely stated, "The best offense is a good defense." So if it is a possibility your adult children may need to return home, develop a strategy before they return to reduce the potential for problems and to lay the groundwork for a positive outcome. Remember to seriously consider putting your arrangement in writing to ensure there is a foundation to keep the lines of communication open.

\section{Resources}

Burrell, J. (n.d.). Are you ready for your grown child to move home? Retrieved from http://youngadults.about.com/od/ movinghome/a/Boomerangquiz.htm

\section{References}

${ }^{1}$ Qian, Z. (2012). During the great recession, more young adults lived with parents. Census Brief prepared for Project US2010. Russell Sage Foundation and Brown University. Retrieved from http://www.s4.brown.edu/us2010

${ }^{2}$ Parker, K. (2012). The boomerang generation: Feeling OK about living with mom and dad. Washington, D.C.: Pew Research Center. Retrieved from http://www.pewsocialtrends.org/2012/03/15/the-boomerang-generation/

${ }^{3}$ Arnett, J. J., \& Fishel, E. (2013). When will my grown-up kid grow up? Loving and understanding your emerging adult. New York: Workman Publishing Co.

${ }^{4}$ Kubin, L. L. (2006). When adult children move back home communication on finances is key. Fort Collins: Colorado State University Extension. Retrieved from http://www.ext. colostate.edu/pubs/columncc/cc060828.html

${ }^{5}$ eXtension. (2008). Adult children moving home. Retrieved from http://www.extension.org/pages/15960/ adult-children-moving-home

${ }^{6}$ Forthun, L., Ferrer-Chancy, M., Falcone, A., \& Pergola, J. (2009). Grandparents raising grandchildren: Understanding relationships. UF/IFAS Extension series of publications. Gainesville: University of Florida Institute of Food and Agricultural Sciences. Retrieved from http://edis.ifas.ufl. edu/topic_book_grandparents_raising_grandchildren

${ }^{7}$ Harrison, M. \& Walker, K. (2005). Coping with a money crunch: What to expect when adult children move back home. FCS7007. Gainesville: University of Florida Institute of Food and Agricultural Sciences. http://ufdc.ufl.edu/ IR00001244/00001 
Table 1. Sign-out sheet example

\begin{tabular}{|l|l|l|l|l|l|l|}
\hline Date and time & Borrower & Vehicle & Purpose & $\begin{array}{c}\text { Expected time of } \\
\text { return }\end{array}$ & $\begin{array}{c}\text { Current amount } \\
\text { of fuel }\end{array}$ & $\begin{array}{c}\text { Amount of fuel } \\
\text { upon return }\end{array}$ \\
\hline & & & & \\
\hline & & & & \\
\hline & & & & \\
\hline
\end{tabular}

